\title{
Forms and teaching methods in the system of continuing professional education
}

\section{Formas y métodos de enseñanza en el sistema de formación profesional continua}

\author{
Ludmila A. Sundeeva \\ Togliatti State University, Togliatti, Russia \\ ORCID: https://orcid.org/0000-0002-2205-7986 \\ Elena V. Lukina \\ Minin Nizhny Novgorod State Pedagogical University, Russia. \\ ORCID: https://orcid.org/0000-0003-1437-3337 \\ Lyubov Yu. Shobonova \\ Minin Nizhny Novgorod State Pedagogical University, Russia. \\ ORCID: https://orcid.org/0000-0001-6727-1970 \\ Lyubov I. Kutepova \\ Minin Nizhny Novgorod State Pedagogical University, Nizhny Novgorod, Russia. \\ ORCID: https://orcid.org/0000-0002-3175-4978 \\ Zhanna V. Smirnova \\ Minin Nizhny Novgorod State Pedagogical University, Russia. \\ ORCID: https://orcid.org/0000-0001-9950-9824
}

*Correspondence

Email: ivannovadremova29@gmail.com

\section{Cite as:}

Sundeeva, L., Lukina, E., Shobonova, L., Kutepova, L., Smirnova, Z. (2021). Forms and teaching methods in the system of continuing professional education. Propósitos $y$ Representaciones, 9 (SPE1), e806. Doi: http://dx.doi.org/10.20511/pyr2021.v9nSPE1.806 


\section{Summary}

The search for innovative forms and teaching methods is highly significant in the context of continuing education, since the competitiveness of modern teachers depends on the quality of the continuing education process. The purpose of the article is to analyze the experience of using innovative forms and methods in the system of advanced training and professional retraining of students. The article presents the experience of organizing the work of students using modern forms and methods of advanced training. The implementation of video conferencing allows students to learn advanced professional experience, exchange relevant information, ask leading experts questions of interest and receive recommendations. Training activities contribute to the intensification of the learning process. It is aimed both at mastering the cognitive component of the information transmitted by the teacher, and the formation of new professional models of behavior that meet modern requirements for the implementation of pedagogical activity. Mental maps are a means of logical structuring of information and are aimed at its operational development. Project activities allow students to build professional competence, find new innovative ways to solve problems, assess the feasibility and effectiveness of project ideas.

Key Words: videoconferencing, advanced training, professional retraining, design activities, training activities.

\section{Resumen}

La búsqueda de formas y métodos de enseñanza innovadores es muy significativa en el contexto de la educación continua, ya que la competitividad de los docentes modernos depende de la calidad del proceso de educación continua. El propósito del artículo es analizar la experiencia de utilizar formas y métodos innovadores en el sistema de formación avanzada y reciclaje profesional de los estudiantes. El artículo presenta la experiencia de organizar el trabajo de los estudiantes utilizando formas y métodos modernos de formación avanzada. La implementación de la videoconferencia permite a los estudiantes adquirir experiencia profesional avanzada, intercambiar información relevante, hacer preguntas de interés a los principales expertos y recibir recomendaciones. Las actividades de formación contribuyen a la intensificación del proceso de aprendizaje. Tiene como objetivo tanto el dominio del componente cognitivo de la información que transmite el docente, como la formación de nuevos modelos profesionales de conducta que cumplan con los requisitos modernos para la implementación de la actividad pedagógica. Los mapas mentales son un medio de estructuración lógica de la información y están dirigidos a su desarrollo operativo. Las actividades de proyectos permiten a los estudiantes desarrollar competencias profesionales, encontrar nuevas formas innovadoras de resolver problemas, evaluar la viabilidad y eficacia de las ideas de proyectos.

Palabras clave: videoconferencia, formación avanzada, reciclaje profesional, actividades de diseño, actividades formativas.

\section{Introducción}

Analyzing the ways of professional education development, we can talk about the demand for professional retraining and advanced training courses. The introduction of new Federal state educational standards, the Informatization of education, and the development of scientific and technological progress make it necessary to develop new professional areas within the framework of professional and pedagogical activities (Gladkov et al., 2019). Continuing education of teachers acts as a guarantee of their professional improvement, maintaining and increasing competitiveness, professional mobility and demand (Klinkov, 2018).

The purpose of the article is to analyze the experience of implementing modern forms and methods of training in the system of additional professional education. 
In this article, we consider the practice of preparing students for courses at the Institute of directed professional education. For example, students learn the courses "Theory and methods of teaching in an educational organization", "Current problems of modern education".

To date, professional retraining of teachers is carried out in areas that are in demand in the labor market (Tsarapkina et al., 2019a). The courses are intended for teachers of different levels, including preschool. For example, the course "Theory and practice of preschool education" and others are being implemented for them.

Within the framework of the competence-based educational paradigm, the planned results of additional professional programs are defined in the competence format (Vaganova et al., 2019b).

Professional retraining refers to the formation of additional competencies (Vaskovskaya, 2018), which are necessary to perform the functions of a new line of professional activity or obtain additional qualifications using modern forms and methods that contribute to the activation of the learning process (Vaganova et al., 2019a).

Professional development is an update of students' theoretical and practical knowledge necessary for mastering innovative methods of solving professional problems (Pichugina \& Bondarchuk, 2019).

At the Institute of directed education in Togliatti, various forms and methods are used in the training of students as part of the implementation of advanced training courses (Chertovskikh, 2019). These include round tables, discussion clubs, masterclasses, workshops, consultations, and others. In connection with updating the requirements for professional retraining and advanced training, we are introducing innovative forms and methods (Vaganova et al., 2019c). For example, training activities and video conferences, mental maps, project activities, and other forms and methods are used.

Training activities allow analyzing and improving professional behaviors (Andrienko, 2019b). This feature allows us to talk about it as one of the most competitive tools for developing students' competencies.

The advantages of training activities also lie in their practical orientation (Pliushch, 2018). According to $\mathrm{Yu}$. R. Chirkov, the training form of training is the best way to transfer practical skills.

Video conferences are group telecommunications (Vaganova, 2019e) that allow data exchange from a personal computer.

The use of mental maps allows you to structure information into blocks, which contributes to its best memorization. There is no need for students to study a large amount of information in text form.

Project activities allow us to focus on professionally-oriented activities (Donetskova, 2019). In contrast to training activities, project activities are aimed at obtaining the final educational product. It is based on forecasting (Tsarapkina et al., 2019a), planning, research, development, and decision-making displayed in project documentation, layouts, and models.

The famous psychologist J. Raven in his book considered projects as a way to form highlevel competencies through improving such qualities as initiative, responsibility, ability to interact, solve emerging problems and tasks through independent observation (Raven, 2017). 
If mental maps are largely focused on working with text information and relate to the development of theory by students, then the implementation of project activities is aimed at the practical part of training students.

The implementation of innovative forms and methods of training is accompanied by the use of information technologies (Ponachugin \& Lapygin, 2019). E-learning elements are one of the most modern directions of professional education development (Petrichev et al., 2018). Combining classroom training with electronic elements makes it possible to improve the quality of professional development (Ilyashenko, 2019b). Video banks, technical means for conducting webinars, multimedia equipment are used (Oros, 2018). experience.

In the process of professional development, students learn the most advanced scientific

\section{Theoretical framework}

Our research is based on the works of scientists who studied professional retraining and advanced training as one of the links of continuing education. Among them, we note the A. I. Kravchenko, Z. V. Mozgova, A. I. Kolesnikov and others. The works of A. A. Verbitsky, S. I. Zmeev, Yu. N.Kulyutkin and others are devoted to the study of the problems of training students for advanced training courses. Among the scientists who have made a significant contribution to the organization of educational activities in the framework of the system of additional education should be identified A. I. Kukuyev, D. Savichevich, B. Samolovcheva and others. Cirdan examines the forms and methods of training students in the implementation of innovative educational technologies (Cirdan, 2019). Andrienko O. A. reveals the use of effective forms and methods of organizing classes in modern educational technologies (Andrienko, 2019).

M. V. Alexandrova, V. G. Vorontsova, and N. M. Chegodaev cover the concepts of additional professional education of teachers and the use of effective forms and methods of training. M. N. Dokuchaeva reveals the features of the system of professional development within the University.

Increasing demand for educational services for professional retraining makes it necessary to improve the existing practice of advanced training and professional retraining (Fix \& Troshchinskiy, 2015), search for modern forms and methods of implementing the educational process (Grigoriev et al., 2019).

\section{Methodology}

The research was conducted based on the Institute of directed professional education in the city of Togliatti as part of advanced training courses for teachers. The work was carried out in 2019.

It was attended by 48 students (3 groups).

The courses are aimed at forming additional competencies of teachers that ensure the ability and readiness to carry out professional activities in modern conditions (Pinkovetskaia, et al, 2020).

Innovative educational methods and forms were actively used in the educational process.

To evaluate the forms and methods of training in the study, as well as to identify the level of satisfaction with the implemented courses in General, questionnaires were conducted covering students of advanced training courses of the Institute of directed education (Chil Núñez et al, 2020). Each student was asked to answer some questions that reflect the assessment of training 
sessions, identification of effective forms and methods of training, comfort of the educational process, and others.

\section{Results and discussion}

Some classes are held in full-time, and some classes are held remotely. The online video conference format provides for the exchange of best practices and the acquisition of new relevant information on education issues. Video conferences are subject to certain rules and have specific goals and objectives. These classes are attended by researchers who can ask questions, exchange opinions, and get recommendations.

Video conferences contribute to deeper assimilation of material by listeners (Filchenkova, 2019). In addition, listeners have the ability to view video recordings in any convenient location at any convenient time, ensuring that listeners maintain mobility.

In the course of training, video conferences were held on the topics of organizing educational activities in modern conditions. At a video conference dedicated to the topic "Legal framework for educational activities". Specialists from different regions took part in the discussion of the topic. The most discussed issues were the formation of legal support for teaching activities and the specifics of its use in educational practice, the regulation of legal relations arising from the provision of educational services.

Experts exchanged views on the impact of modern legislation on the professional activities of teachers, discussed the process of implementing educational programs using innovative educational technologies in accordance with the requirements of Federal state educational standards.

During the development of advanced training courses, students take part in training activities. Training helps to intensify the learning process. The teacher gives exercises that allow students to actively engage in the work. Students develop the skills of setting priorities, managing time, making effective independent decisions, learn the principles of teamwork and effective team interaction, work out new ways of behavior and experiment with them. To enhance performance, the process of implementing training activities is often recorded on video. After that, students have the opportunity to review the material and identify the pros and cons of their training.

In the course of project activities, students improve their theoretical knowledge and develop practical skills. Based on the information received, students independently formulate the problem, analyze the materials, make a project plan and deal with its immediate implementation.

In the system of professional development, the experience of drawing up a mental map is of interest.

Mental maps are a means of logical structuring of information and are aimed at the rapid development of information. Using mind maps, students build mental associations, a starting point which is the Central object. Project activities allow students to develop their professional competence. Find new non-standard ways to solve problems, evaluate the feasibility and effectiveness of project ideas.

The students are divided into subgroups and develop for yourself a step by step guide is divided into blocks. Drawing up a mental map is often carried out on the electronic educational platform Moodle. Students can use any solution to create a map. These can be color solutions, images that define Central concepts and ideas, from which branches diverge to other ideas, concepts, and actions. In the process of developing mental maps, listeners form the integrity of the perception of the activity. They perform operations with sequences, lists, and numbers. The essence of mental maps is to identify the main concept, from which ideas, tasks, thoughts, steps 
necessary for the implementation of a specific project, ideas branch off. The development of mental maps allows the teacher to organize the relationships, for example, between individual topics of the discipline, to pay attention to controversial issues. Mental maps are an effective solution for evaluating activities, including planning, executing, monitoring, and protecting project work. Students of advanced training courses most often use maps when studying the issues of teaching methods in various industries, using certain technologies, methods and tools. Each of the students chooses different methods and techniques, taking into account modern training requirements.

We have evaluated the forms and methods of training students in advanced training courses. To do this, a survey was conducted among the students. They were asked to choose the most effective forms and methods used in their preparation.

The results of the survey are shown in figure 1 .

What forms and methods do you think have proven to be the most effective in the learning process?

- What forms and methods were used?

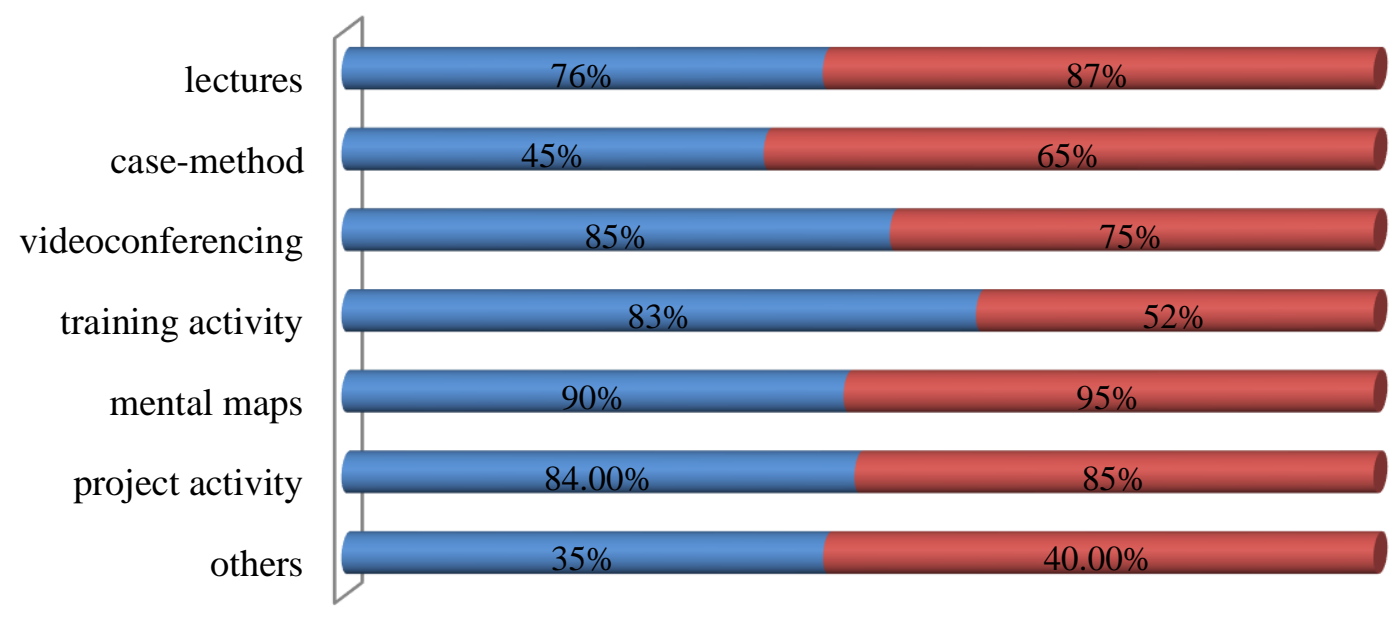

Fig. 1. Results of statistical processing of survey data for advanced training courses (as part of our research)

Based on the data obtained, we can say that the students note the high performance of project activities and the use of mental maps. The importance of training activities and video conferences is highlighted. According to observations, the training activity differs from the main mass as the most effective form of training according to the audience.

Most often, training involves mental maps, lectures, and project activities. At the same time, according to the audience, regular use of mental maps has a positive impact on the results of training. Comprehensive implementation of project and training activities, the use of mental maps and videoconferencing allows you to expand the training opportunities for students of advanced training courses.

The generalized results on the students' satisfaction with the quality of the services provided are shown in figure 2 . A high level is characterized by complete satisfaction with the courses, an average level is partial, and a low level means that the student is not satisfied with the quality of educational services provided. 


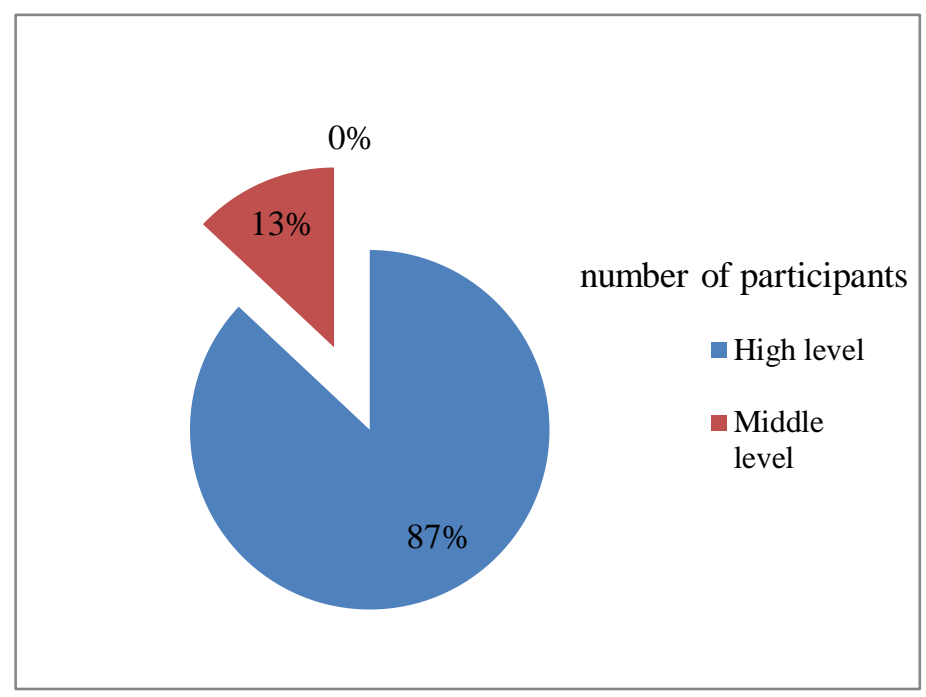

Fig. 2. The level of students' satisfaction of studying in advanced training courses (as part of our research)

\section{Conclusions}

We realize the experience of using innovative forms and methods in the system of advanced training and professional retraining of students. Among them, mental maps and project activities were highlighted as the most effective methods of training, as well as video conferences and training activities as actual forms of training students. The use of mental maps allows you to structure information into blocks, which contributes to its best memorization. There is no need for students to study a large amount of information in text form. Project activity allows students to increase their professional competence, find new non-standard ways to solve problems and evaluate the feasibility and effectiveness of project ideas. The implementation of video conferences allows students to learn the best professional practices, exchange relevant information, ask leading experts questions and get recommendations. The advantages of training activities also lie in their practical orientation. It is aimed at both mastering the cognitive component of the information transmitted by the teacher, and the formation of new professional behaviors.

The results of the study showed values that reflect the high significance of these forms and methods, as well as a high level of satisfaction with the quality of services provided in General. From this, we can conclude that the comprehensive implementation of the analyzed forms and methods allows us to expand the training opportunities for students of advanced training courses and to form the necessary additional competencies for professional activities in modern conditions.

\section{References}

Andrienko, O.A. (2019a). On the need to apply gaming training technologies. Balkan Scientific Review, 2(4), 5-8.

Andrienko, O.A. (2019b). Modern educational technologies: technology of self-presentation. Balkan Scientific Review, 1(3), 5-7.

Chertovskikh, O.O. (2019). Prospects for the use of digital resources in education. Baltic Humanitarian Journal, 8, 4(29), 184-187. 
Chil Núñez, I., Escalona Arranz, J., Molina Bertrán, S., Dutok Sánchez, C., Arias Ramos, D., Pérez Rondón, L., Ochoa Pacheco, A., \& Picanço Souto, R. (2020). Perfeccionamiento de la estrategia curricular de medio ambiente de la carrera de ciencias farmacéuticas de la Universidad de Oriente, Cuba. Revista Científica Del Amazonas, 3(5), 6-17. https://revistadelamazonas.info/index.php/amazonas/article/view/24/21

Cirdan, A.P. (2019). Innovative technologies of professional training of future economists in the system of continuous education. Humanitarian Balkan Research, 2(4), 27-30.

Donetskova, O.YU. (2019). Modernization of the modern education system in Russia. Baltic Humanitarian Journal, 8, 2(27), 37-39.

Filchenkova, I.F. (2019). Educational management of innovative activity of teachers as an object of pedagogical research. Vestnik of Minin University, 7(4).

Fix, N. P., \& Troshchinskiy, V. V. (2015). Business game to eliminate violations of the normal operation of the power system. Business Game on Elimination of an Emergency in the Electric Power System. Modern problems of science and education, 1 (part 1).

Gladkov, A.V., Vaganova, O.I., \& Prokhorova, M.P. (2019). Modern pedagogical technologies as a means of enhancing educational motivation. Baltic Humanitarian Journal, 8, 1(26). 274276.

Grigoriev, S. G., Shabunina, V. A., Tsarapkina, Ju. M., \& Dunaeva, N. V. (2019). Electronic library system as a means of self-development of students of digital generation $\mathrm{Z}$ (on the example of studying the course "Basics of the counselor activity"). Scientific and technical libraries, 7, 78-99. 29.

Klinkov, G.T. (2018). The specificity of manifestation of pedagogical communication as a special construct. Scientific Vector of the Balkans, 1, 51-52.

Oros, I.I. (2018) The role of international connections in the development of the adult education system. Humanitarian Balkan Research, 1, 57-59.

Petrichev, P. V., Masyuk, N. N., \& Bushueva, M. A. (2018). Method of estimation of the effectiveness of the partnership russian universities with foreign educational organizations. Azimuth of Scientific Researches: Economics and Management, 7, 3(24), 229-232.

Pichugina, G.A., \& Bondarchuk, A.I. (2019). Structure of the training case in the organization of the educational process. Humanitarian Balkan Research, 2(4), 5-7.

Pinkovetskaia, I.S., Lyubovtseva, E.G., Arbeláez-Campillo, D.F., \& Rojas-Bahamón, M.J (2020). Small and medium enterprises in Russia and other countries. Amazonia Investiga, 9(25), 99-106. https://amazoniainvestiga.info/index.php/amazonia/article/view/1034

Pliushch, V.M. (2018). Independent work of students as a factor of improving education quality. Balkan Scientific Review, 1, 69-71.

Ponachugin, A.V., \& Lapygin, Yu.N. (2019). Digital educational resources of the university: design, analysis and expertise. Vestnik of Minin University, 7(2), 5.

Raven, J. (2017). Education and Sociocybernetics. Azimuth of Scientific Researches: Economics and Management, 6, 3(20), 289-297. 
Tsarapkina, Ju. M., Dunaeva, N. V., \& Kireicheva, A. M. (2019b). Application of BYOD technology in education on the example of Lecture Racing mobile application. Informatics and Education, 9(308), 56-64.

Tsarapkina, Ju.M., Petrova, M.M., Mironov, A.G., Morozova, I.M., \& Shustova, O.B. (2019a). Robotics as a basis for Informatization of education in children's health camp. Amazonia Investiga, $8(20)$. https://www.amazoniainvestiga.info/index.php/amazonia/article/view/70

Vaganova, O.I., Konovalova, E.Yu., Abramova, N.S., Lapshova, A.V., \& Smirnova, Z.V. (2019a). Increasing the level of teachers' readiness for pedagogical project. Amazonia Investiga, $8(22)$, 286

294. https://www.amazoniainvestiga.info/index.php/amazonia/article/view/445

Vaganova, O.I., Odarich, I.N., Popkova, A.A., Smirnova, Z.V., \& Lebedeva, A.A. (2019b). Independent work of students in professional educational institutions. Amazonia Investiga,

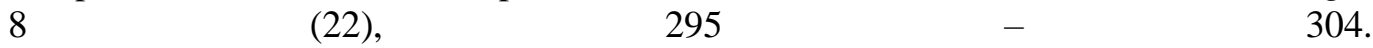
https://www.amazoniainvestiga.info/index.php/amazonia/article/view/447

Vaganova, O.I., Sirotyk, S.D., Popkova, A.A., Smirnova, Z.V., \& Bulaeva, M.N. (2019c). Additional education in higher professional educational institution. Amazonia Investiga, $8(22)$, 305

310. https://www.amazoniainvestiga.info/index.php/amazonia/article/view/448

Vaskovskaya, G.A. (2018). Features of implementation of pedagogical technologies of profile training. Balkan Scientific Review, 1, 76-79. 